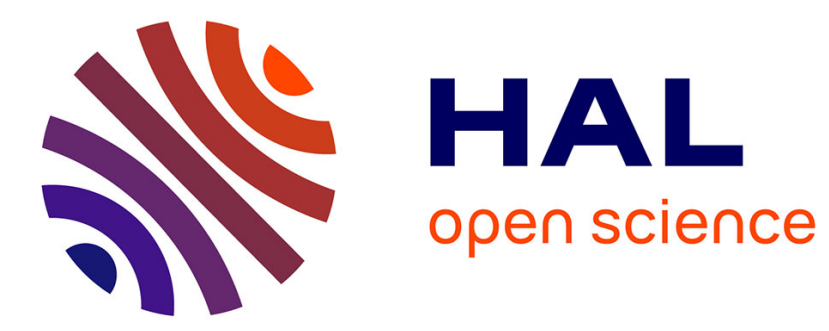

\title{
Effect of block copolymer nano-reinforcements on the low velocity impact response of sandwich structures
} Karthik Ram Ramakrishnan, Sandra Guerard, Philippe Viot, Krishna Shankar

\section{To cite this version:}

Karthik Ram Ramakrishnan, Sandra Guerard, Philippe Viot, Krishna Shankar. Effect of block copolymer nano-reinforcements on the low velocity impact response of sandwich structures. Composite Structures, 2014, 110, pp.174-182. 10.1016/j.compstruct.2013.12.001 . hal-00925232

\section{HAL Id: hal-00925232 https://hal.science/hal-00925232}

Submitted on 7 Jan 2014

HAL is a multi-disciplinary open access archive for the deposit and dissemination of scientific research documents, whether they are published or not. The documents may come from teaching and research institutions in France or abroad, or from public or private research centers.
L'archive ouverte pluridisciplinaire $\mathbf{H A L}$, est destinée au dépôt et à la diffusion de documents scientifiques de niveau recherche, publiés ou non, émanant des établissements d'enseignement et de recherche français ou étrangers, des laboratoires publics ou privés. 


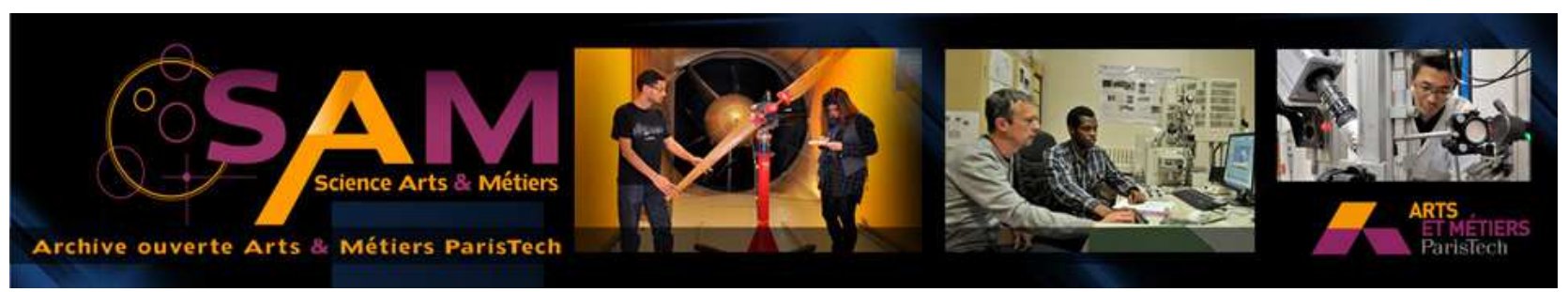

Science Arts \& Métiers (SAM)

is an open access repository that collects the work of Arts et Métiers ParisTech researchers and makes it freely available over the web where possible.

This is an author-deposited version published in: http://sam.ensam.eu

Handle ID: .http://hdl.handle.net/10985/7676

\section{To cite this version :}

Karthik Ram RAMAKRISHNAN, Sandra GUERARD, Philippe VIOT, Krishna SHANKAR - Effect of block copolymer nano-reinforcements on the low velocity impact response of sandwich structures - Composite Structures - Vol. 110, p.174-182 - 2014 


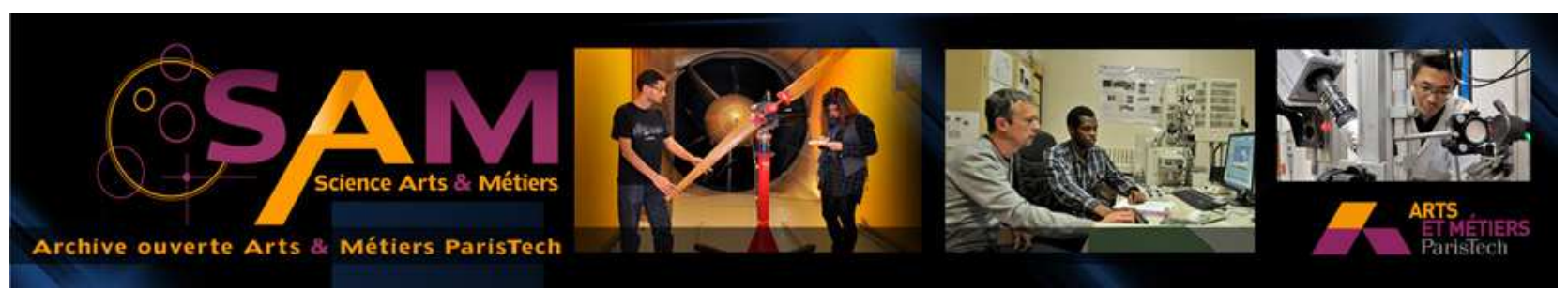

Science Arts \& Métiers (SAM)

is an open access repository that collects the work of Arts et Métiers ParisTech researchers and makes it freely available over the web where possible.

This is an author-deposited version published in: http://sam.ensam.eu

Handle ID: .http://hdl.handle.net/null

\section{To cite this version :}

Sandra GUERARD, Philippe VIOT, Krishna SHANKAR, Karthik Ram RAMAKRISHNAN - Effect of block copolymer nano-reinforcements on the low velocity impact response of sandwich structures - Effect of block copolymer nano-reinforcements on the low velocity impact response of sandwich structures - Vol. 110, p.174-182 - 2014 


\title{
Effect of block copolymer nano-reinforcements on the low velocity impact response of sandwich structures
}

\author{
Karthik Ram Ramakrishnan ${ }^{\mathrm{a}, \mathrm{b}, *}$, Sandra Guérard ${ }^{\mathrm{a}}$, Philippe Viot ${ }^{\mathrm{a}}$, Krishna Shankar ${ }^{\mathrm{b}}$ \\ ${ }^{a}$ Arts et Métiers ParisTech, I2M-DuMAS, UMR 5295, F-33400 Talence, France \\ ${ }^{\mathrm{b}}$ School of Engineering and Information Technology, UNSW, Canberra 2600, Australia
}

Keywords:

Block copolymer

Drop tower

Low velocity impact

Kevlar

Sandwich

\begin{abstract}
A B S T R A C T
Sandwich composites with fibre reinforced plastic (FRP) facesheets have emerged as a major class of lightweight structural materials in a wide range of engineering fields including aerospace, automotive and marine structures. This is due to attractive mechanical properties such as high specific stiffness and high strength. However, sandwich structures are susceptible to damage caused by impact. The objective of this paper is to evaluate the dynamic response of sandwich composites based on Kevlar fibre reinforced epoxy and Rohacell ${ }^{\circledR}$ foam. The improvement in impact performance of these sandwich structures that can be achieved by the addition of nanoparticles in the resin matrix is investigated. Nanostrength ${ }^{\circledR}$, an acrylate triblock copolymer that self-assembles in the nanometer scale is added to the epoxy matrix. The effect of the nano-reinforcements on flat sandwich plates under low velocity impact is investigated at different scales. An instrumented drop tower setup is used for the low velocity impact tests of the sandwich plates with neat or nano-reinforced epoxy matrix, at different energies. The macroscopic response of the sandwich structure and the microscopic phenomena involved in dissipating the impact energy are identified and compared for sandwich plates with and without nanoparticles.
\end{abstract}

\section{Introduction}

The sandwich structure is based on a simple construction of two thin high strength facesheets bonded to either side of a thick low density core such as foams and honeycombs. This provides a lightweight structure with high stiffness. The skins are designed to resist tensile and compressive stresses and are usually made of aluminium or fibre reinforced polymers. The core is designed to resist compression and shear stresses and is usually made of wood, polymer foams, or expanded metal or polymer honeycombs. Sandwich composites with fibre reinforced plastic (FRP) facesheets and foam cores have emerged as a major class of lightweight structural materials in a wide range of engineering fields including aerospace, automotive and marine structures. One of the main drawbacks of these high performance structures is their relatively poor resistance to impact loading [1]. Impact damage in sandwich structures can be caused by tool drops, runway debris, bird strikes, hailstorms or ballistic loading. The damage caused by low-velocity impact may result in drastic reduction of stiffness and residual strength of the sandwich composite [2]. Ballistic impacts cause localized damage which is clearly visible on inspection while low-velocity

* Corresponding author at: Arts et Métiers ParisTech, I2M-DuMAS, UMR 5295, F-33400 Talence, France.

E-mail address: karthik.ramakrishnan@adfa.edu.au (K.R. Ramakrishnan). impacts involve long contact time between impactor and target which result in global structural deformation with internal damage at points far from the contact region [1]. Extensive delamination and core damage were observed in specimens with no visible surface damage [3], indicating the importance of studying the low velocity impact response of sandwich structures.

Richardson and Wisheart [4] identified low-velocity impact as impacts where the contact duration is long enough for the entire structure to respond to the impact load. The upper limit of what constitutes a low velocity impact has been defined by different researchers as either under $10 \mathrm{~m} / \mathrm{s}$ or impact speeds up to $100 \mathrm{~m} / \mathrm{s}$ [4]. The low-velocity impact damage of sandwich plates is typically tested using a drop tower test facility [5]. Many researchers have conducted low velocity impact tests on sandwich panels composed of different facesheets and core materials [6-10]. There has been considerable effort to improve the impact resistance of sandwich structures [11-14]. Dvorak and Suvorov [11] investigated the effect of placing a ductile interlayer between the facesheet and the foam core. The brittle nature of the epoxy matrix and its lack of resistance to crack growth is one of the limiting factors on the impact performance of the FRP sandwich structures [15]. Epoxy resins are one of the most commonly used resins because of their properties, such as thermal stability, mechanical response and low density [16]. Epoxy resins are the matrix material for glass-, Kevlar- and other fibre reinforced composites in 
many applications. Shih et al. [17] reported that the impact failure mechanism of sandwich panels containing less tough facesheets was found to change from facesheet-dominated to foamcore-dominated behaviour. Attempts to reduce matrix damage and improve the interlaminar fracture toughness of thermoset resins has involved incorporating plasticizing modifiers, or adding rubber or thermoplastic particles to the resin. Many researchers have investigated various methods to toughen the matrix with additives such as rubber $[15,18]$. However, the drawback of this approach is that it sacrifices the stiffness of epoxy significantly and decreases the glass transition temperature. One of the proposed solutions is the modification of the thermoset resins with nano-sized organic and inorganic particles. Carbon nanotubes (CNT), carbon nanofibres and nanoclays were identified as potential nano-scale materials for the reinforcement of epoxy [19,20,12-14]. Hosur et al. [12] studied the improvement in low velocity impact response of sandwich plates due to the addition of nanoclays both in the facesheets as well as the polyurethane foam core. They identified different failure mechanisms in the sandwich panels with nanoclay and concluded that it was possible to sustain higher loads, reduce the damage size during impact like events and lower the reduction in mechanical properties by adopting nanophased sandwich construction. Avila et al. [13] studied the effect of adding nanoclay to fibre glass/epoxy system and its use as facesheet in a sandwich structure. The authors varied the percentage of nanoclay present in the epoxy resin and studied the low velocity impact response of a GFRP/PS Foam sandwich plate. Their preliminary results however suggest that the improvement in the stiffness and impact resistance of sandwich structures due to the nanoclay is minimal.

While most of the research has been focussed on carbon nanotubes (CNT) or nanoclay and silicate nanocomposites, a new method to synthesize block copolymers which self-assemble in the nanoscale was reported by Barsotti [21]. This would appreciably reduce the problems associated with dispersion of the nanoparticles. Nanostructuration is induced by the strong repulsions between the side and middle block. The thermodynamic miscibility of the block copolymer leads to a homogeneous and reproducible dispersion on a nanometer scale. The author claimed that using triblock polymers consisting of polymethylmethacrylatepolybutylacrylate- polymethylmethacrylate (MAM) and styreneb-butadiene-b-polymethylmethacrylate (SBM) families enhanced the fracture toughness and impact performance with minimal sacrifice of thermal properties [21]. A systematic study on the effect of these nano reinforcements on the mechanical performance of FRPs made with these nano-modified resins, especially to impact loading, is lacking. Denneulin et al. [16,22] identified the dearth of literature on composites with nano-elastomers of block copolymer and studied the influence of Nanostrength embedded in the matrix, on the low velocity impact response of Kevlar fibre reinforced composite structures. Denneulin [22] reported that while the carbon nanotubes did not have significant effect, the addition of the nanoparticles of block copolymer to the resin improved the impact resistance of the Kevlar FRP and prevented catastrophic failure due to fibre breakage and perforation seen in the sample without the nanoparticles.

The paper aims to compare the low velocity impact response of sandwich structures with and without Nanostrength in the epoxy matrix. The sandwich structures chosen for the study have facesheets made of Kevlar fibre reinforced epoxy laminates and a core made of closed cell PMI foam. A series of low velocity impact tests are performed using an instrumented drop tower. The forcedisplacement curves of the sandwich panels, the energy absorbed during impact and post-mortem observations are employed to compare the impact resistance of sandwich structures.

\section{Manufacturing of samples}

\subsection{Material}

The sandwich panels with the Kevlar fibre reinforced epoxy skins were manufactured using a wet layup process. Kevlar129 (Saatilar Style 802; Taffeta $190 \mathrm{~g} / \mathrm{m}^{2}$; thickness: $260 \mu \mathrm{m}$ ) was chosen for this study because of its very high tensile toughness $\left(\sigma_{r}\right.$ $=3.4 \mathrm{GPa}, \epsilon_{r}=3.5 \%$ ). Sandwich composites with Kevlar fabric facesheets were shown to possess the best impact resistance and the least extent of damage compared to glass, carbon and carbon/Kevlar hybrid facesheets [10]. Three layers of plain woven fabric with the ply orientation $[0 / 90]$ were used. Closed cell Rohacell ${ }^{\circledR}$ PolyMethacryImide (PMI) foam with a density of $51 \mathrm{~g} / \mathrm{cm}^{3}$ was chosen as the core material for the sandwich panels.

The DGEBA thermoset epoxy resin Epolam and hardener supplied by Axson Technologies was used. The hardener was used in the ratio $0.345(\mathrm{w} / \mathrm{w})$ (34.5 $\mathrm{g}$ of hardener for $100 \mathrm{~g}$ of resin) as recommended by supplier. For the resin with nano-reinforcements,

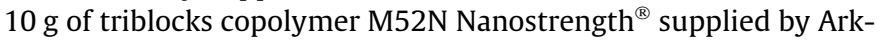
ema was added to $100 \mathrm{~g}$ of Epolam resin. Denneulin et al. have shown from tests on Kevlar composites with three different formulations of block copolymer (M22, M42, and M52N) that 10\% M52N Nanostrength ${ }^{\circledR}$ in the epoxy resin system provided the best performance with regard to perforation resistance [16]. Nanostrength ${ }^{\circledR}$ which is in powder form is added to the resin by mixing, using a mechanical stirrer at $290 \mathrm{rpm}$ at $110^{\circ} \mathrm{C}$ for a duration of $2 \mathrm{~h}$. Transmission Electronic Microscopy (TEM) was used by Denneulin et al. [16] to check the self-assembling process of the block copolymer nanoparticles.

\subsection{Method of fabrication}

The sandwich samples were manufactured using a wet lay-up process. The different steps involved in the fabrication of the sandwich plate are shown in the Fig. 1. The manufacturing process was similar to the method explained in [16]. In the first step, each layer of Kevlar fabric cut to desired dimensions was impregnated with the resin-hardener mix manually (with a brush). The three impregnated layers of fabrics were placed between two sheets of baking paper and compressed in the press for $5 \mathrm{~min}$ at room temperature and a pressure of 1.5 bars. This step ensures that excess resin is ejected from the facesheet. The step was repeated for both the top and bottom facesheet of the sandwich. The two facesheet layers of $[0 / 90]_{3}$ Kevlar fibre were then bonded on each side of the core material and the sandwich panel was co-cured in a hot press at $90^{\circ}$ for $90 \mathrm{~min}$. No additional adhesive was introduced between the face sheets and the core. Co-curing the facesheets ensured good adhesion with the core. Finally, the sandwich composites were post-cured in an oven at $80^{\circ} \mathrm{C}$ for $2 \mathrm{~h}$. Square plates of length $200 \mathrm{~mm}$ were fabricated using this method. The nominal thickness of the cured sandwich plates was $20 \mathrm{~mm}$.

\section{Experimental setup}

Low velocity impact testing was accomplished using a drop tower. The drop tower setup consists of an instrumented impactor that is secured to a carriage that falls along guideposts and collides with the plate. An electromagnet holds the carriage lifted to a predetermined height and the impact event is initiated by switching off the electromagnet and letting the carriage fall freely under the action of gravity. The impactor head transfers the impact energy to the test specimen. The drop height is varied to give a range of impact energies while the mass of the impactor is kept constant. The maximum impact energy that can be obtained is limited by the 


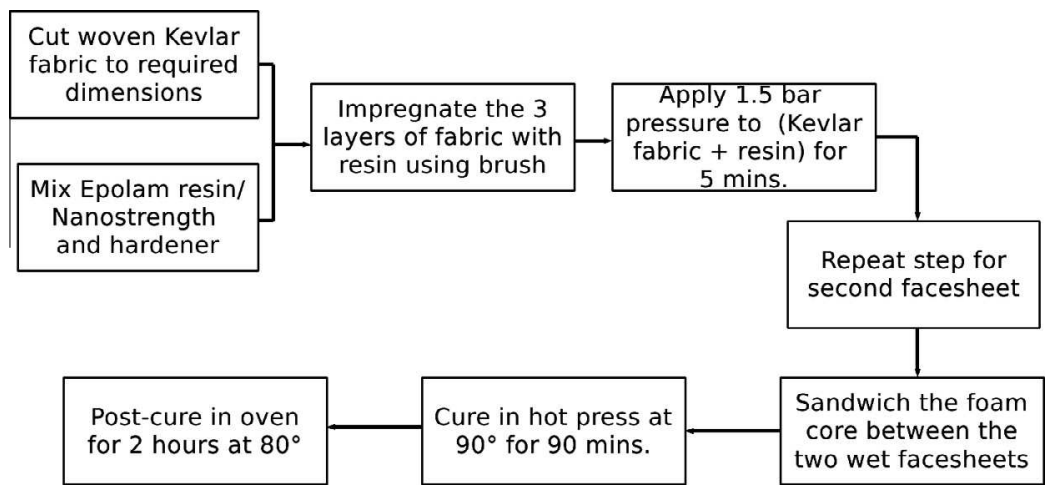

Fig. 1. Steps involved in the fabrication of sandwich samples.

weight of the impactor carriage and the maximum height of the tower. The drop tower setup used for the low velocity impact testing is shown in Fig. 2.

The drop tower consists of two rectified columns attached to a metallic gantry and these two columns guide the falling carriage, on which different impactor geometries can be fixed. A winch with an electromagnet was used to lift the projectile to the desired impact height. During the test, the impactor carriage is released by the electromagnet, freefalls, and strikes the structure. A reboundcatcher has been implemented to avoid a second impact, which could further damage the structure and prevent a post-mortem analysis of the damage and residual strain. The force response of the sandwich structure during impact was measured using a piezoelectric force sensor (Kistler force transducer, force range of $5 \mathrm{kN}$ ). The signals of both sensors were recorded by a National Instruments card acquisition at a frequency of $30 \mathrm{kHz}$. In addition to these sensors, two high-speed video cameras (Photron FASTCAMAPX RS and Photron SA3) were used to measure displacement of the impactor and to observe the top facesheet, respectively. The initial velocity was obtained by a linear regression of the displacement before contact.

\subsection{Initial conditions}

The sandwich plates without the nanoparticles in the facesheets are designated KR sandwich plate (to denote Kevlar-Rohacell sandwich) while the plates with Nanostrength embedded in the epoxy matrix are designated KNR sandwich plate (Kevlar-Nanostrength-Rohacell sandwich). The sandwich panels were tested for three drop heights of $0.5 \mathrm{~m}, 0.75 \mathrm{~m}$ and $1 \mathrm{~m}$ corresponding to impact energies $8 \mathrm{~J}, 12 \mathrm{~J}$ and $16 \mathrm{~J}$. The initial energy of the impact was calculated from the mass of the impactor $(1.8 \mathrm{~kg})$ and initial

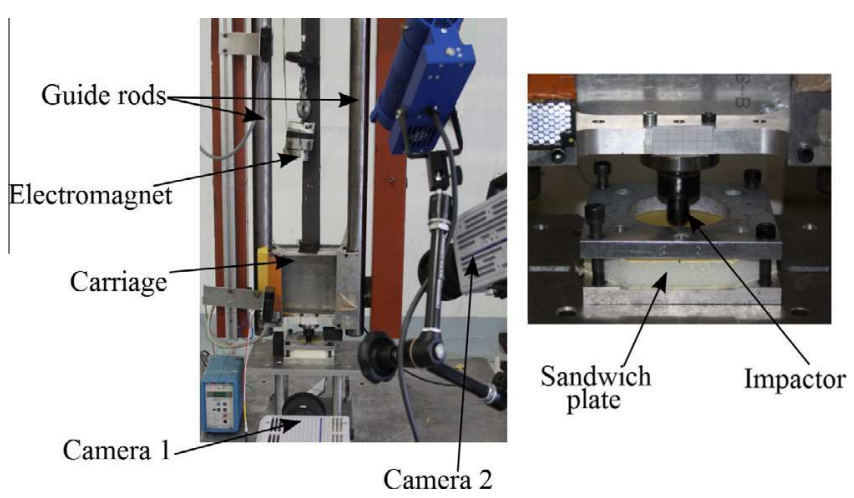

Fig. 2. Drop tower setup for low velocity impact testing. impact velocity found from the slope of the displacement before contact. The $16 \mathrm{~mm}$ diameter hemispherical headed impactor strikes the centre of the square target plate which is clamped with square aluminium plates with a circular hole of diameter $70 \mathrm{~mm}$. The bolts were tightened to a torque of $5 \mathrm{~N} \mathrm{~m}$ using a torque wrench, in order to provide consistent clamping from experiment to experiment.

A typical force and displacement-time history of low velocity impact is shown in Fig. 3. The curves shown correspond to $8 \mathrm{~J} \mathrm{im}$ pact on KR sandwich plate. Time $t_{0}$ and $t_{3}$ corresponds to the beginning and end of impact, respectively. It can be seen that the total duration of the impact is about $10 \mathrm{~m} \mathrm{~s}$. The contact force of the sandwich composite exhibits a linear increase with respect to time as the indenter comes into contact with the specimen and is followed by a sudden drop in the load after it reached the first peak value at $t_{1}$. The maximum displacement of the impactor occurs at $t_{2}$ and marks the beginning of the unloading phase. The unloading is finally followed by the rebound, which is represented by the contact force value reaching zero i.e. the impactor is no longer in contact with the sandwich plate $\left(t_{3}\right)$.

\section{Results of drop tower test}

The measurements of time-history of force and displacement made it possible to plot the force vs. displacement curve for each type of sandwich plate tested. In order to verify the repeatability of the test, three samples were tested at each energy. Fig. 4 shows the force-displacement curves for KR sandwich plate impacted with an initial energy of $8 \mathrm{~J}$. It can be observed from these curves that only a weak dispersion of material behaviour exists between

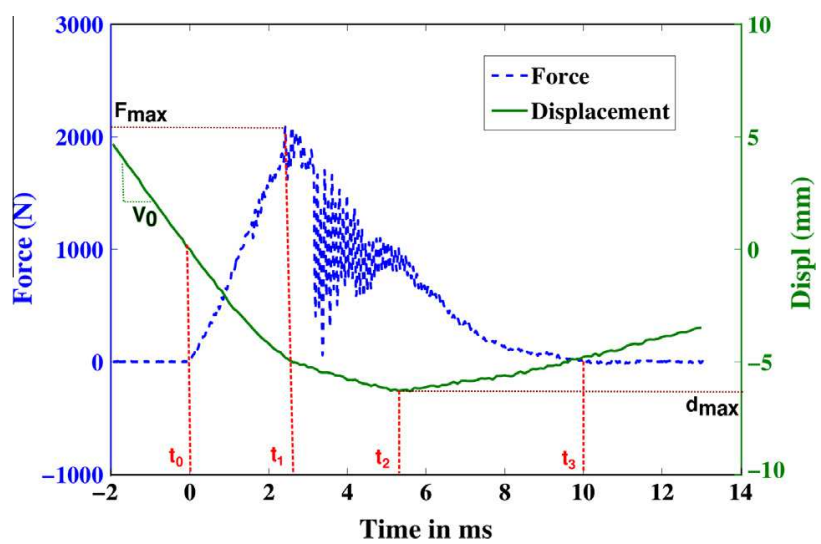

Fig. 3. Typical force and displacement-time history of low velocity impact on sandwich panels $(8 \mathrm{~J})$. 


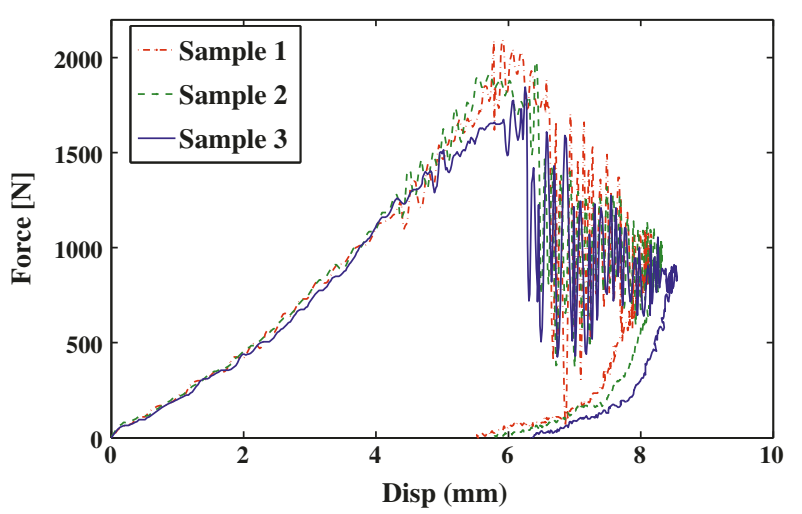

Fig. 4. Force-displacement curve of low velocity impact of KR sandwich panels $(8 \mathrm{~J})$.

the different samples. The initial linear portion of the curve is robust while the large oscillations that marked the beginning of fibre breakage are not reproducible. However, it is safe to assume that the tests are repeatable and only a representative sample from each energy is used for comparison with other samples henceforth.

Figs. 5-7 show the force-displacement plot for the KevlarRohacell sandwich with neat resin and with $10 \%$ M52N Nanostrength at different impact energies. The samples shown correspond to impact energies of $8 \mathrm{~J}, 12 \mathrm{~J}$ and $16 \mathrm{~J}$ (drop height of $0.5 \mathrm{~m}, 0.75 \mathrm{~m}$ and $1 \mathrm{~m}$ ) for KR and KNR sandwich plates respectively. The force-displacement curve of KR and KNR sandwich plates are compared for the three different impact energies. It is observed that the force-displacement curve of the sandwich panels show a quasi-linear behaviour for low values of indentation, followed by a non-linear regime. It can also be observed that the stiffness of the sandwich panel during the elastic bending phase, i.e. slope of the linear portion of the curve, the elastic stiffness is reduced by the addition of copolymers, which is likely due to the more compliant elastomeric phase. However, the stiffness has not changed dramatically for the sandwich plate with the nanoparticles. This is particularly important as the toughening of the resin with rubber particles resulted in a considerable loss of stiffness. The behaviour of the KNR sandwich is distinctly different from the KR sandwich, including the quantitative values of peak force and maximum displacement. For the sandwich with neat resin (KR), a sharp drop in force is observed which corresponds to the failure of facesheets through fibre breakage and perforation. The behaviour after this peak exhibits a core-dominant behaviour and follows regions of plastic plateau in which the cellular structure collapse initiate by buckling of the cell walls and edges and densification of the core. The second peak seen for sandwich plates impacted at the higher energy shows that the lower facesheet has begun to play a role in the deformation.

Typical images of the top facesheet post-impact are also shown in the Figs. 5-7. There is considerable difference in the failure observed in the KR and KNR sandwich plates. It can be seen that even for the lower energy, there is beginning of fibre failure and perforation in the sandwich plates with neat resin. There is complete penetration of the top facesheet in the neat resin sandwich impacted at higher energy. The sandwich plates with nano-modified resin does not show any perforation but some failure in the fibre directions, i.e. [0-90], is clearly visible. It can also be observed from visual examination of the top facesheet that the load is spread over a larger area for the samples with nano-modified resin while the sandwich plate with neat resin shows more local damage. It can be concluded that the KNR sandwich plate exhibits a higher strength and an absence of sudden drop in rigidity associated with fibre breakage and perforation of the KR sandwich plate.

Fig. 8 shows the images from the second high speed camera used to observe the top facesheet. The images, corresponding to an impact test at $16 \mathrm{~J}$, begin $6 \mathrm{~m}$ s before the beginning of contact and shows the impactor indent the top facesheet. It can be seen that there is complete perforation of the top facesheet in the case of the impact of KR sandwich plate and prolonged contact whereas the KNR sandwich is able to resist the impact event.

An additional test was carried out at an initial energy of $20 \mathrm{~J}$ (drop height $1.25 \mathrm{~m}$ ) to observe if the KNR sandwich had perforation at this higher energy. Fig. 9 shows the force-displacement curve of the $20 \mathrm{~J}$ impact on KR and KNR sandwich plate and the top and bottom facesheet of the sandwich sample. The second peak observed for KR sandwich is the result of loading on the bottom facesheet. Visual examination of the facesheets after impact show that there is considerable failure in the bottom facesheet of the KR sandwich plate. It can be observed that the $20 \mathrm{~J}$ impact caused penetration failure in the top facesheet of the KNR sandwich plate whereas the bottom skin shows little damage.

The evolution of peak force and maximum displacement vs. the initial energy were plotted in Fig. 10. It can be observed that the peak force values for KNR sandwich show a steady increase up to a maximum of $3180 \mathrm{~N}$ followed by a drop to $2480 \mathrm{~N}$ for the $20 \mathrm{~J}$ impact. This can be explained by the perforation of the top facesheet observed in the $20 \mathrm{~J}$ impact. A corresponding increase in

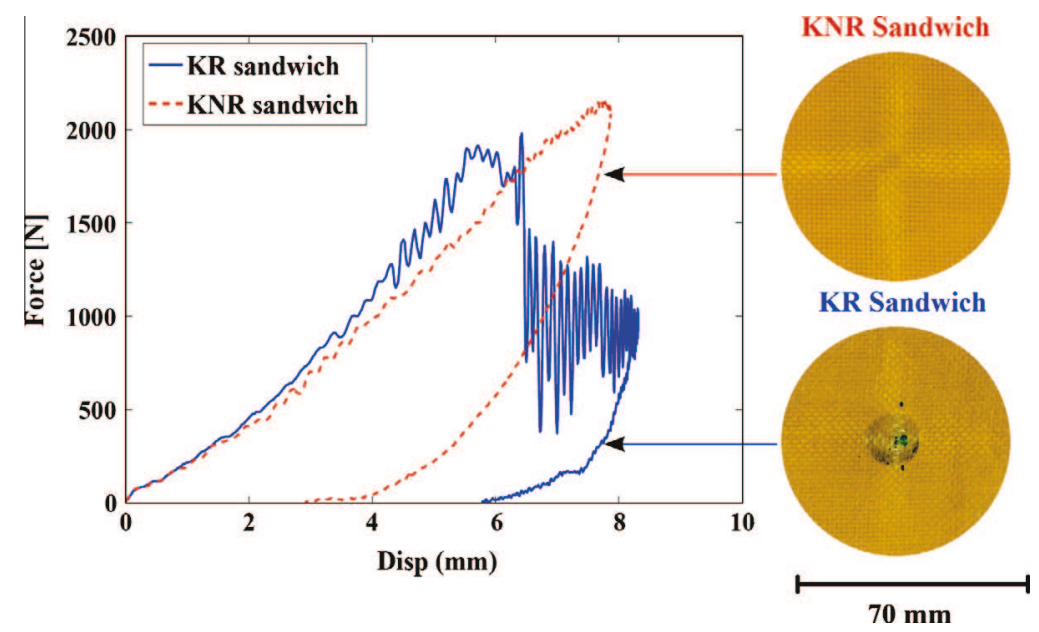

Fig. 5. Force-displacement curves of KR and KNR sandwich plates after $8 \mathrm{~J}$ impact and image of top facesheet after impact. 


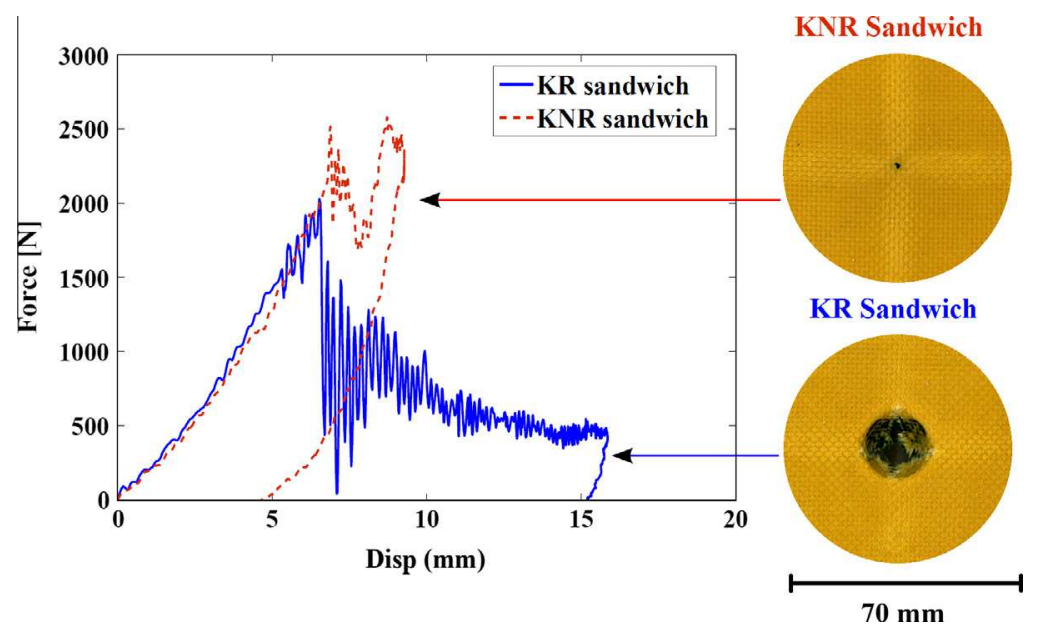

Fig. 6. Force-displacement curves of KR and KNR sandwich plates after $12 \mathrm{~J}$ impact and image of top facesheet after impact.

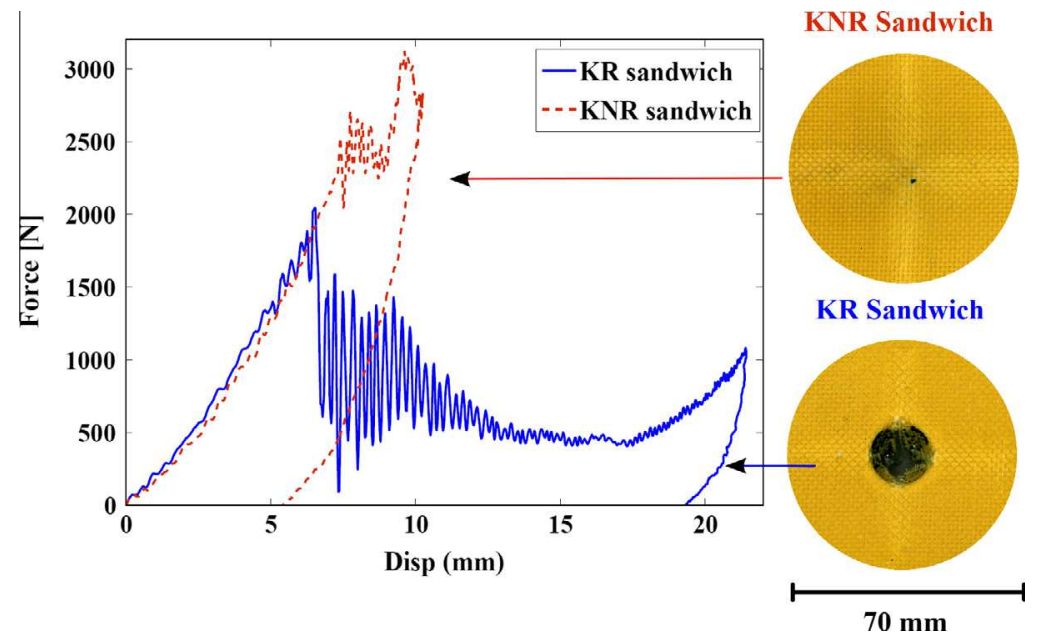

Fig. 7. Force-displacement curves of KR and KNR sandwich plates after $16 \mathrm{~J}$ impact and image of top facesheet after impact.
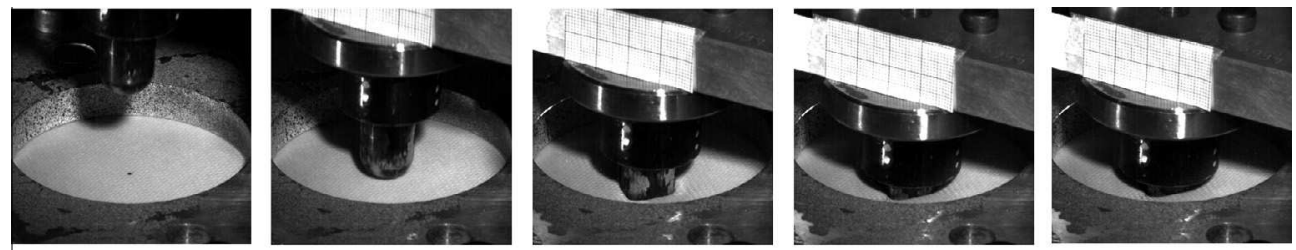

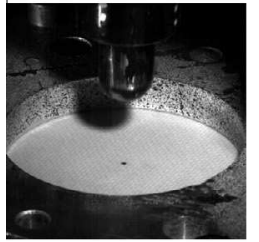

$\mathrm{t}=-6 \mathrm{~ms}$

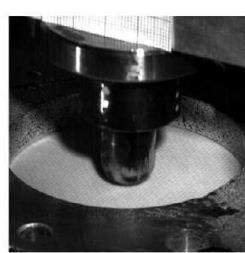

$\mathrm{t}=0 \mathrm{~ms}$

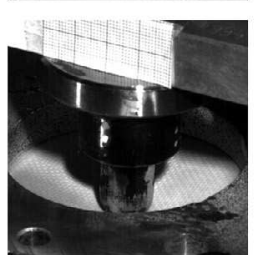

$\mathrm{t}=3 \mathrm{~ms}$

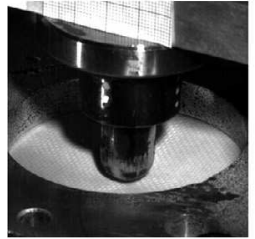

$\mathrm{t}=8 \mathrm{~ms}$

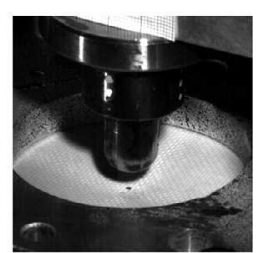

$\mathrm{t}=14 \mathrm{~ms}$

Fig. 8. Comparison of propagation of impact in KR (top) and KNR (bottom) sandwich plates for impact of $16 \mathrm{~J}$.

the maximum displacement is noted. The peak force for KR sandwich plate does not show an increasing trend as the sandwich plate with nano-modified resin. There is a drop in the peak force for the $20 \mathrm{~J}$ impact but there is a second peak corresponding to the deflection of bottom facesheet. The maximum displacement continues to show an increasing trend to a maximum of $26.3 \mathrm{~mm}$ for the $20 \mathrm{~J}$ impact.

\subsection{Energy absorbed}

Denneulin et al. [16] defined the energy until the initiation of the perforation, computed as the integral of the force-displacement curve up to the displacement corresponding to the peak force. This energy represents the elastic energy of the plate, the energy dissipated by matrix damage, the energy dissipated by friction 


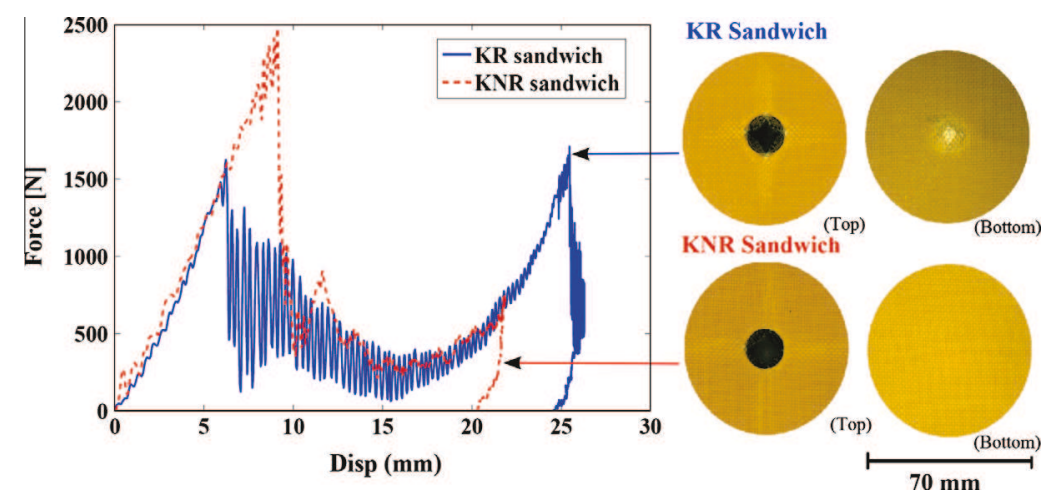

Fig. 9. Force-displacement curves of KR and KNR sandwich plates after $20 \mathrm{~J}$ impact and image of top and bottom facesheet after impact.
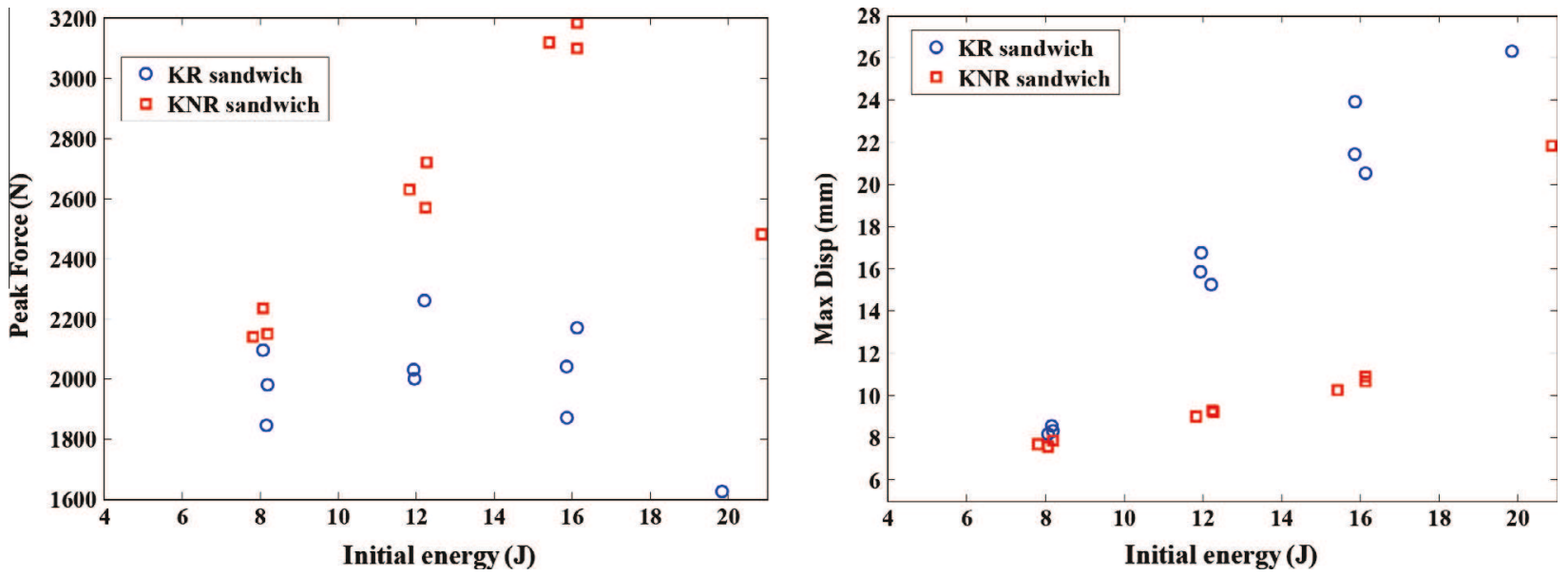

Fig. 10. Evolution of peak force and maximum displacement.

and by wave propagation in the experimental setup. The energy up to the peak force clearly represents the energy required to generate sufficient damage to reduce the stiffness of the plate and affect its structural integrity severely, and was calculated from the integral of the force-displacement curve. The energy required to initiate failure for the KR and KNR sandwich plates is compared in Fig. 11. It is observed that the elastic energy has similar trend to the results presented by Reis et al. [20] for the addition of nanoclay particles. The KNR sandwich with nanoparticles has comparable energy absorbed at the lower energy of impact but at higher energies, the sandwich with nanoparticles clearly absorbs more energy. This is due to increasing peak force before the initiation of damage. According to Denneulin et al.[16], a ranking regarding perforation resistance can be performed with this criterion. A polynomial fit was not attempted given the limited number of impact energies tested, but the trends are shown as dotted lines and it is evident that the addition of Nanostrength ${ }^{\circledR}$ increases the penetration threshold for the Kevlar sandwich plates.

A second criterion can also be defined as the total energy dissipated during the impact. This corresponds to the total area under the force-displacement curve from the beginning of impact until the end of unloading phase when the force reaches zero again. This energy represents the residual elastic energy of the plate. The total energy dissipated is plot against the initial kinetic energy of the impactor (shown in Fig. 12). The $45^{\circ}$ line is the total available energy, i.e. for initial impact energy of $8 \mathrm{~J}$, the maximum energy that

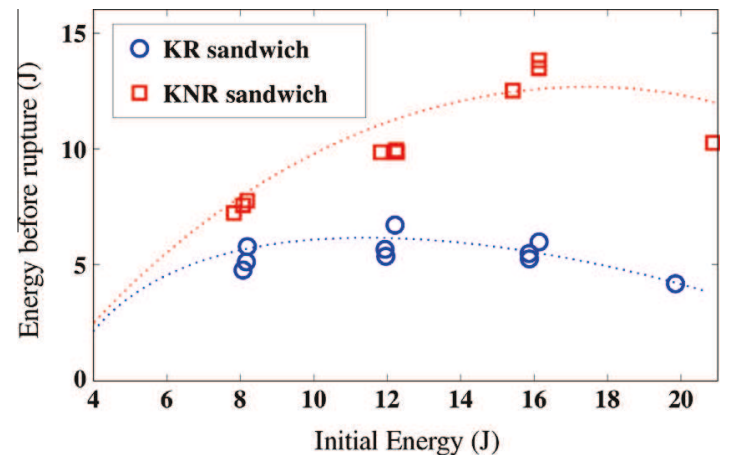

Fig. 11. Energy up to peak force.

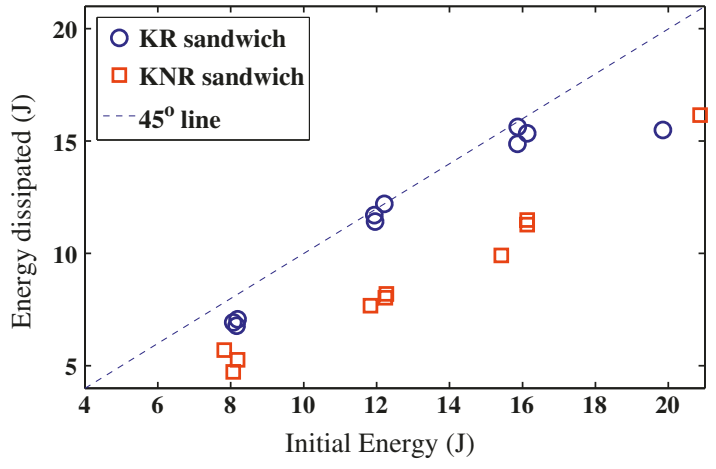

Fig. 12. Total energy dissipated in the impact 

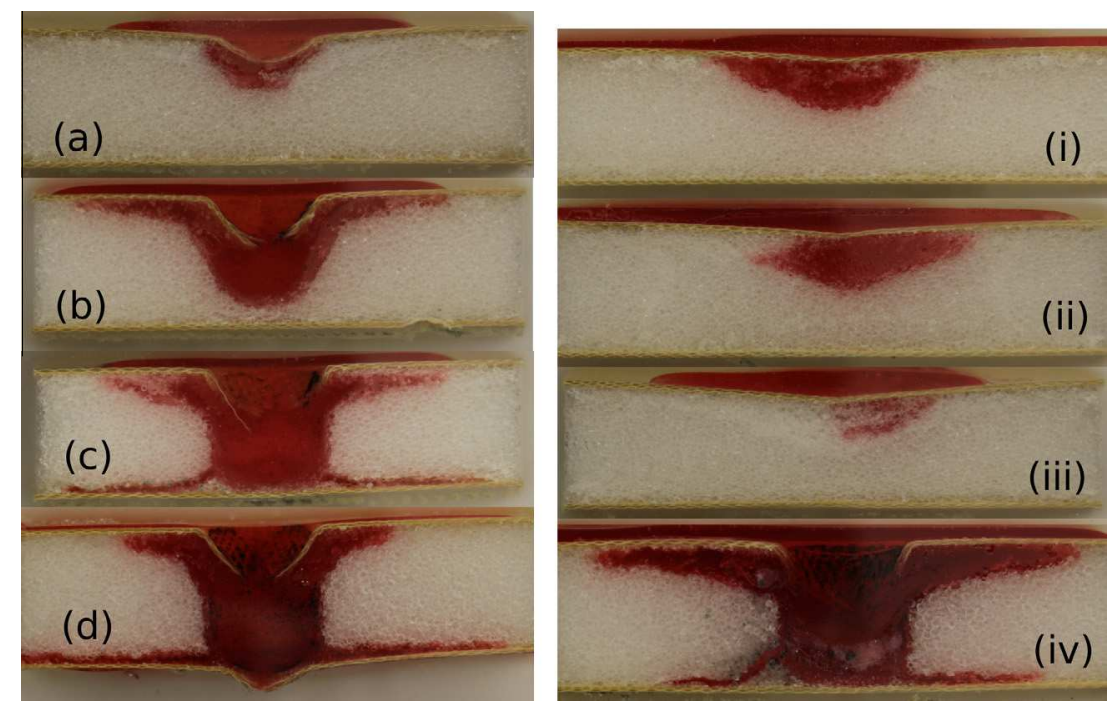

Fig. 13. Comparison of cross-section of sandwich plate (a-d) KR sandwich, (i-iv) KNR sandwich.

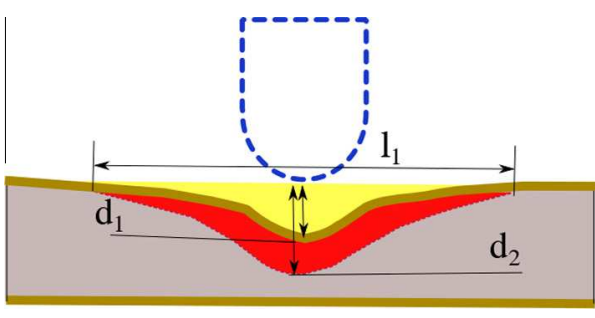

Fig. 14. Defining the damage parameters.

can be dissipated during the impact is $8 \mathrm{~J}$ and so on. It can be seen that penetration occurs when the dissipated energy curve approaches the $45^{\circ}$ line, i.e. samples that undergo penetration absorbs a large portion of the kinetic energy of the impactor in damage of the different components of the sandwich plate. The KR sandwich has higher total energy absorbed because of the perforation of the facesheet and extensive core crushing. The maximum displacement reached for the $16 \mathrm{~J}$ impact is almost $22 \mathrm{~mm}$. This core dominated region is involved in dissipating a large portion of energy. Even though the KNR sandwich plates have a higher peak force value than the KR sandwich counterparts, there is sufficient recovery of the samples in the unloading phase, that it has a lower total energy dissipated. It is understood that higher values of dissipated energy relates to lower elastic recovery and consequently major damage while the lower values of the sandwich plate with nanoparticles implies that the KNR sandwich plate can withstand impact loading of energy upwards of $16 \mathrm{~J}$ before failing by perforation. It is also interesting to note that for the impact at $20 \mathrm{~J}$, the KR sandwich plate has reached a saturation limit and the higher energies does not cause an increase of this value. The KNR sandwich continues to have an increasing trend in the energies tested and has not reached the saturation limit.

\subsection{Post-mortem damage analysis}

The impacted sandwich sample is cut in the middle in order to observe the section view. The sandwich sample is mounted with a coloured resin before cutting to preserve the shape of the damage of the facesheets as well as the core. For the sandwich plates where there is no perforation of the top facesheet, a small hole is drilled on the top facesheet, through which the coloured resin is injected. A room temperature curing epoxy resin was used along with a red dye for this purpose. The sandwich plate was cut using a diamondtoothed saw and the section of interest is embedded in a clear
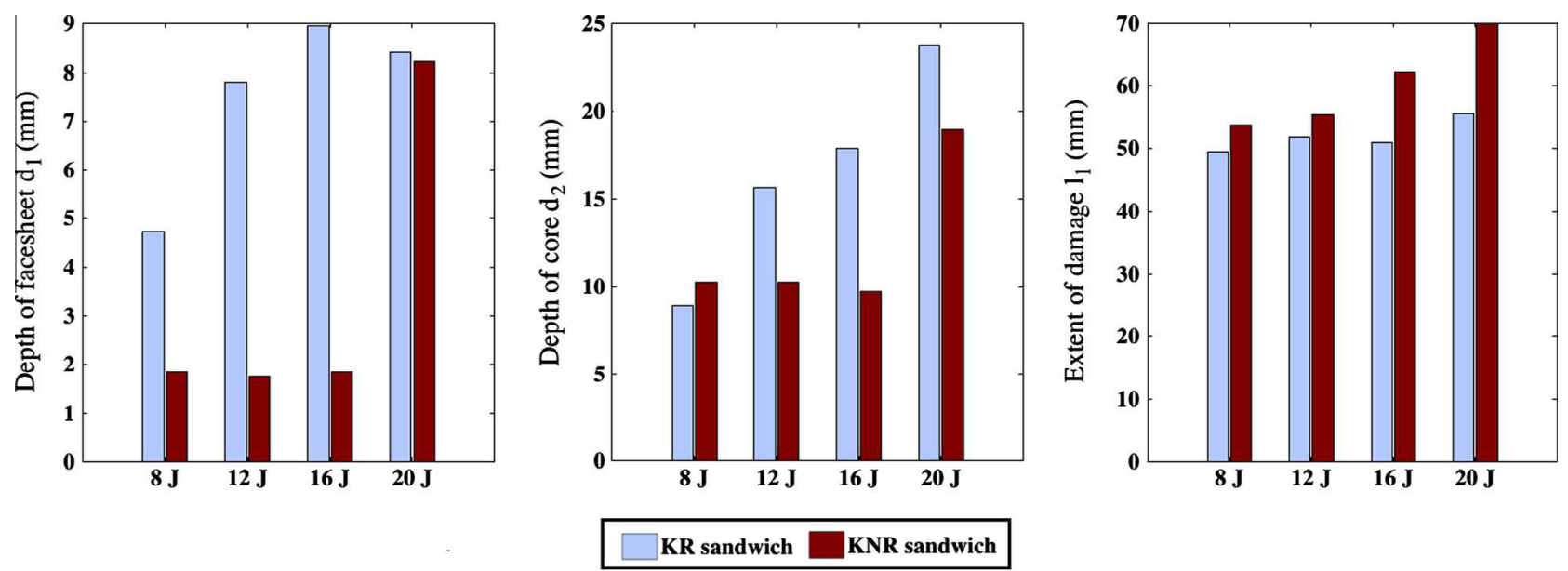

Fig. 15. Different damage parameters measured from section of the sandwich sample. 


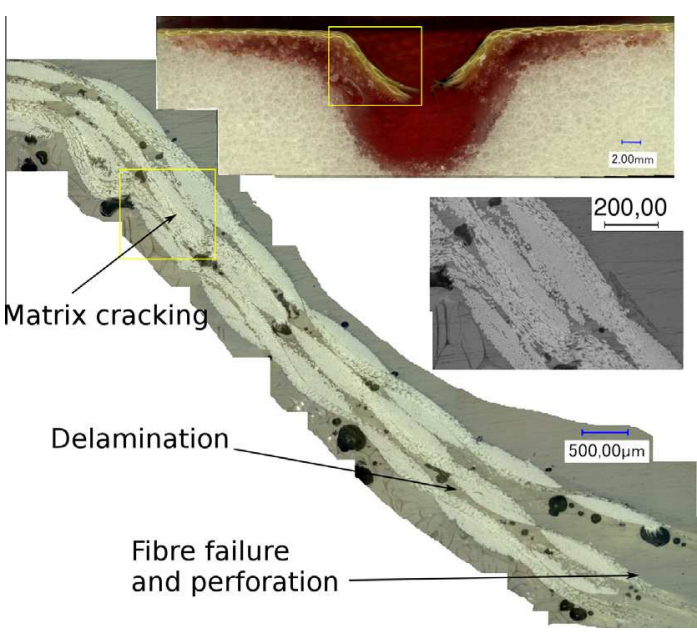

Fig. 16. Microscopic observations of section of KR sandwich (12 J impact).

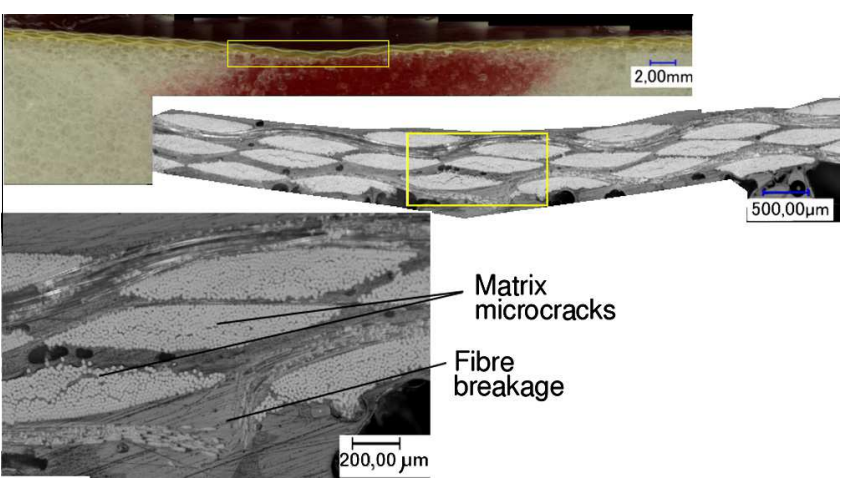

Fig. 17. Microscopic observations of section of KN sandwich (16 J impact).

Mecaprex resin under vacuum. The mounted samples are then polished under progressively finer abrasive papers. The section view of the KR and KNR sandwich plates for impact energies of 8,12 , 16 and $20 \mathrm{~J}$ are shown in Fig. 13. Visual examination of the impacted samples highlight that for many cases with considerable damage in the top facesheet, the lower facing of the sandwich structure was undamaged. There was no damage in the bottom facesheet unless there was penetration of the top facesheet and extensive core crushing. Energy absorption is maximized through the sandwich construction, as penetration through all the three components (top facesheet, core, and bottom facesheet) is required for the complete failure of the sandwich structure. The KNR sandwich impacted at $20 \mathrm{~J}$ for instance, has perforation in the top facesheet but the bottom skin is intact which would allow for more energy to be dissipated before complete failure of the sandwich plate.

It can also be observed in samples impacted at $20 \mathrm{~J}$ (image (d) and (iv)), that the penetration of the top facesheet resulted in extensive damage in the core region immediately below the point of impact. This resulted in debonding between the bottom facesheet and core, where the red coloured resin can be clearly observed. The visual examination also confirms that the bottom facesheet of the KR sandwich plate has considerable fibre failure under $20 \mathrm{~J}$ impact.

Three damage parameters are defined from the sections of the impacted specimen as shown in Fig. 14. They are:

1. Depth of indentation of the top facesheet $\left(d_{1}\right)$.

2. Depth of indentation of the core $\left(d_{2}\right)$.

3. Width of debonding between facesheet and core $\left(l_{1}\right)$.

The section view of the KR sandwich plates shows the extensive core crushing just below the point of impact (displayed as the redcoloured resin). There is also some debonding between the top facesheet and the core where the red resin has penetrated. Debonding occurs because the laminated facesheet is able to recover it's shape during the unloading phase of the impact while the crushable foam cannot. It can be observed that the damage is concentrated in the local area around the point of impact. There is no perforation in the top facesheet of the KNR sandwich except at the highest energy level. Since the resin is injected through a tiny hole, it does not penetrate the region between the facesheet and the core as well. However, the area of damage is clearly distinguishable as a different colour. There is considerable damage to the core and the debonding between the facesheet and core is spread over a larger area.

Fig. 15 shows the comparison of the different damage parameters for the KR and KNR sandwich plates. It can be seen for KR sandwich plates that both the depth of indentation in facesheet and core $\left(d_{1}\right.$ and $\left.d_{2}\right)$ exhibit an increasing trend with initial energy while the KNR sandwich shows an almost constant value. The higher values observed for the KR sandwich plates are due to the more local damage observed in them. The extent of damage $l_{1}$ which corresponds to the amount of debonding between the top facesheet and the core have higher values for KNR sandwich plates which confirm that the load is spread over a larger area in the sandwich plate with nano-reinforcements.

\subsection{Microscopic observations of the sandwich plates}

The section of the sandwich plate is also observed under an digital optical microscope. Microscopy reveals three prominent modes of failure in the top facesheet; matrix cracking, delamination, fibre breakage and perforation. The KR sandwich plate after an impact of $12 \mathrm{~J}$ is shown in Fig. 16. It can be seen that the damage in the KR

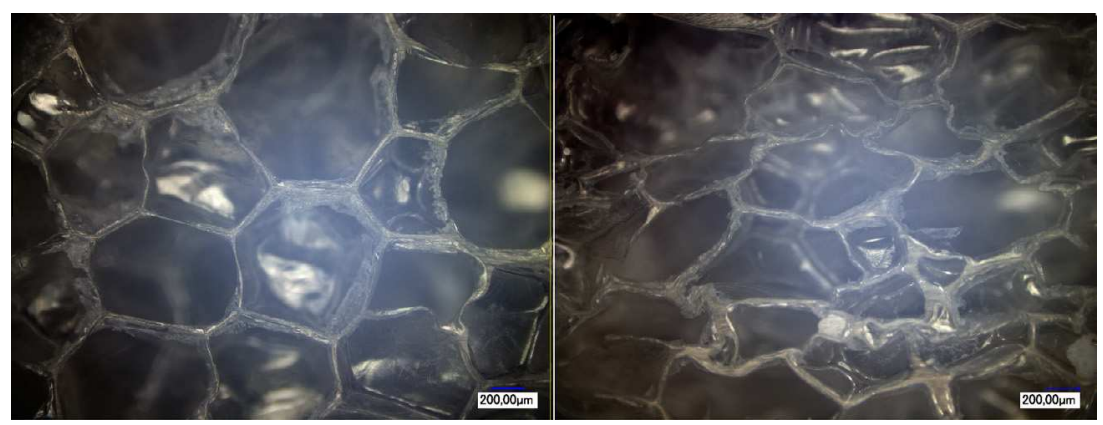

Fig. 18. Uncrushed and crushed cells of PMI foam (impact of $12 \mathrm{~J}$ ). 
sandwich plate was concentrated in the indentation zone corresponding to the dimensions of the impactor. Fibre breakages are clearly visible close to the point of impact. In the second zone, a gap can be detected between the three layers of the Kevlar fabric, corresponding to the delamination failure. Finally, matrix cracking is observed in the $90^{\circ}$ fibre yarns.

KNR sandwich plate after an impact of $16 \mathrm{~J}$ is shown in Fig. 17. A high density of matrix cracks between $90^{\circ}$ fibre yarns is observed in the sandwich plates with nanoparticles. These matrix cracks are mainly responsible for the dissipated energy. It is hypothesised that these matrix cracks and the resulting delamination are responsible for the increase in dissipation of the impact energy before initiation of failure. It is also interesting to note that the matrix cracks are not limited to the impact zone but are present farther from the point of impact as well.

Fig. 18 shows the uncrushed and crushed cells of the Rohacell ${ }^{\circledR}$ foam core for $12 \mathrm{~J}$ impact. Buckling of the cell walls can be clearly observed in the crushed core. The foam core plays an important role in the energy absorbed by the sandwich structure as a large amount of energy is dissipated in the core crushing.

\section{Conclusions and recommendations}

The objective of this research was to evaluate the effect of including block copolymer nanoparticles to the matrix on the low velocity impact behaviour of sandwich composites based on Kevlar fibre reinforced epoxy and PMI foam. A 10\% M52N Nanostrength ${ }^{\circledR}$ triblock copolymer was chosen for the study. Kevlar fabric was chosen for their good properties under dynamic loading and their application in impact resistant structures. A drop weight tower was used to conduct low-velocity impact tests on the two types of sandwich plates at different initial energies. The effect of the nano-reinforcements on the sandwich plates under lowvelocity impact was firstly studied at the macroscopic level. A comparison of sandwich panels in terms of the energy absorbed by the panel was undertaken. The KNR sandwich plates required higher energy to fail and also did not exhibit perforation failure of the facesheets as the sandwich plates without the nanoreinforcements. The damage in the foam core was also not localised in the impact zone but was spread across a significant part of the structure. Different damage parameters were described to compare the two types of sandwich structures. While the KR sandwich plate failed by perforation, no perforation was detected in the top facesheet for the sandwich plate with nanoreinforcements for the same impact energy. Perforation of top facesheet was observed in KR sandwich plates for impact at $12 \mathrm{~J}$ whereas KNR sandwich plates did not have perforation even at $16 \mathrm{~J}$ impact. Optical microscopy was undertaken to observe the different failure mechanisms in the Kevlar facesheet. It is observed that the damage phenomena in the KNR sandwich plate consist mainly of matrix cracking and it is proposed that this may explain the improvement in impact resistance. It can be concluded that the M52N elastomeric nanoparticles significantly improved the resistance of Kevlar FRP sandwich structures under low velocity impact.

\section{References}

[1] Bhuiyan M, Hosur M, Jeelani S. Low-velocity impact response of sandwich composites with nanophased foam core and biaxial braided face sheets. Compos Part B: Eng 2009;40(6):561-71. http://dx.doi.org/10.1016 j.compositesb.2009.03.010.

[2] Wang J, Waas AM, Wang H. Experimental and numerical study on the lowvelocity impact behavior of foam-core sandwich panels. Compos Struct 2013;96(0):298-311. http://dx.doi.org/10.1016/i.compstruct.2012.09.002.

[3] Bernard ML, Lagace PA. Impact resistance of composite sandwich plates. J Reinf Plast Compos 1989;8(5):432-45. http://dx.doi.org/10.1177/073168448900 $\underline{800502 .}$

[4] Richardson M, Wisheart M. Review of low-velocity impact properties of composite materials. Compos Part A: Appl Sci Manuf 1996;27(12):1123-31. http://dx.doi.org/10.1016/1359-835X(96)00074-7.

[5] Anderson T, Madenci E. Experimental investigation of low-velocity impact characteristics of sandwich composites. Compos Struct 2000;50(3):239-47. doi: 10.1016/S0263-822(00)00098-2.

[6] Gustin J, Mahinfalah M, Jazar GN, Aagaah M. Low velocity impact of sandwich composite plates. Compos Sci Technol 2004:44(6):574-83.

[7] Cantwell W, Dirat C, Davies P. A comparative study of the mechanical properties of sandwich materials for nautical construction. SAMPE J 1994;30(4):45-51.

[8] Hazizan MA, Cantwell WJ. The low velocity impact response of foam-based sandwich structures. Compos Part B: Eng 2002;33(3):193-204. doi: 10.1016/ S1359-8368(02)00009-4..

[9] Mines R, Worrall C, Gibson A. Low velocity perforation behaviour of polymer composite sandwich panels. Int J Impact Eng 1998;21(10):855-79. http:// dx.doi.org/10.1016/S0734-743X(98)00037-2.

[10] Xia F, Wu X. Work on low-velocity impact properties of foam sandwich composites with various face sheets. J Reinf Plast Compos 2010;29:1045-54. doi: 10.1177/0731684409102749.

[11] Dvorak GJ, Suvorov AP. Protection of sandwich plates from low-velocity impact. J Compos Mater 2006;40(15):1317-31. http://dx.doi.org/10.1177/ $\underline{0021998305059053}$.

[12] Hosur M, Mohammed A, Zainuddin S, Jeelani S. Processing of nanoclay filled sandwich composites and their response to low-velocity impact loading. Compos Struct 2008;82:101-16. http://dx.doi.org/10.1016/i.compstruct. 2006.12.009.

[13] Avila AF, Carvalho MGR, Dias EC, da Cruz DT. Nano-structured sandwich composites response to low-velocity impact. Compos Struct 2010;92(3):745-51. doi: 10.1016/j.compstruct.2009.09.010..

[14] Reis PNB, Santos P, Ferreira JAM, Richardson MOW. Impact response of sandwich composites with nano-enhanced epoxy resin. J Reinf Plast Compos 2013;32(12):898-906. http://dx.doi.org/10.1177/0731684413478993.

[15] Bagheri R, Marouf BT, Pearson RA. Rubber-toughened epoxies: a critical review. Polym Rev 2009;49:201-25.

[16] Denneulin S, Viot P, Leonardi F, Lataillade J-L. The influence of acrylate triblock copolymer embedded in matrix on composite structures responses to lowvelocity impacts. Compos Struct 2012;94(4):1471-81. http://dx.doi.org/ 10.1016/i.compstruct.2011.11.021.

[17] Shih W, Jang B. Instrumented impact testing of composite sandwich panels. Reinf Plast Compos 1989;8(3):270-98. http://dx.doi.org/10.1177/0731684489 00800304 .

[18] Garg A, Mai Y-W. Failure mechanisms in toughened epoxy resins - a review. Compos Sci Technol 1988;31(1):179-223. doi: 10.1016 j.compscitech.2005.06.007..

[19] Njuguna J, Pielichowski K, Alcock J. Epoxy-based fibre reinforced nanocomposites. Adv Eng Mater 2007;9(10):835-47. http://dx.doi.org/ 10.1002/adem.200700118.

[20] Reis P, Ferreira J, Zhang Z, Benameur T, Richardson M. Impact response of Kevlar composites with nanoclay enhanced epoxy matrix. Compos Part B: Eng 2013;46(0):7-14. http://dx.doi.org/10.1016/i.compositesb.2012.10.028.

[21] Barsotti R. Nanostrength block copolymers for epoxy toughening. Tech rep, Arkema Inc., September; 2008

[22] Denneulin S. Influence of nanoparticles embedded in matrix on composite structures response to low velocity impacts, PhD thesis. Arts et Métiers ParisTech; 2011. 